\title{
Spatial modelling of multidimensional poverty in rural area: Evidence from Malang Regency, Indonesia
}

\author{
Ismu Rini Dwi Ari*, Septiana Hariyani and Budi Sugiarto Waloejo \\ Brawijaya University, Malang, Indonesia \\ *Correspondence email: dwiari@ub.ac.id
}

\section{ARTICLE INFO}

- Research Article

Article History

Received 20 February 2021

Accepted 5 August 2021

Published 2 October 2021

\section{Keywords}

poverty dimension; participation; density; infrastructure; spatial neighborhood

\section{JEL Classification} A13; I32; R58

\begin{abstract}
Poverty is a multidimensional phenomenon that causes difficulty for people to meet their needs. The research aims to scrutinize physical and social infrastructures concerning multidimensional poverty levels using the spatial approach. Jabung District, Malang Regency, Indonesia has 35\% poor households in this case study. The objectives are to measure multidimensional poverty levels, social capital indices of the rate of participation (RoP) and density, and scrutinize neighborhood relationships among 15 villages using spatial regression analysis. Data collection is through a questionnaire survey of 274 heads of households. The research identified four poverty levels (very low to high), where five villages with high poverty levels (Jabung, Taji, Kemiri, Gunungjati, Slamparejo) became the targeted areas. The majority of the villages had a medium level of both the RoP and density, and the community had moderate social relations among community members. The spatial regression analysis indicates that the attribute of the RoP and weight matrix have a significant impact on the poverty level. It is recommended that poverty alleviation programs should focus upon the cluster of poor villages through social infrastructure development as the action to end poverty.
\end{abstract}

To cite this article: Ari, I. R. D., Hariyani, S., \& Waloejo, B. S. (2021). Spatial modelling of multidimensional poverty in rural area: Evidence form Malang Regency, Indonesia. Journal of Socioeconomics and Development, 4(2), 198-211. https://doi.org/10.31328/jsed.v4i2.2245

ISSN 2615-6075 online; ISSN 2615-6946 print (CUWG Press, 2021

\section{INTRODUCTION}

In the era of SDGs fulfillment, poverty is still a worldwide problem, particularly for developing countries, that have to be tackled by 2030 . Poverty might be a direct result from having very low income or very limited resources which then brings further effects, for instance, undernourishment and hunger, exposure to infectious diseases and mental sickness and drug addiction. Poverty might emerge in a community when it has no basic abilities, no income, no adequate education, bad health condition, no safety, low confidence, or lack of rights such as freedom of speech (UNDP, 2016). Poverty is also a development problem of Indonesia indicated by lack of access to education and health services, insufficient access to hygienic water and sanitation, and difficulties of fulfilling basic needs of food, apparel, and housing (Adhi, 2009).

To reach the first goal of the SDGs, the Indonesian government has several programs to reduce poverty such as Beras Miskin (rice for the needy), Beras Sejahtera (rice for welfare), Bantuan Pangan NonTunai (non-cash food aid), and Bedah Kemiskinan Rakyat Sejahtera (poverty termination for welfare).

Poverty also has an impact on economic activity, especially on government programs. Poverty reduces 
employment and Gross Regional Domestic Product. Local governments should handle regional finances more effectively to reduce poverty, especially community economic activities (Elia et al., 2020). Poverty is a multidimensional phenomenon that causes difficulty for people to get a healthy lifestyle and education (Aminou \& Zahonogo, 2020).

The basic idea of this research is derived from the assumption that understanding the influence of both physical and social infrastructures as well as spatial neighborhood effect might develop an appropriate strategy for dealing with poverty alleviation (Ari et al., 2017). The Multiple Poverty Index (MPI) value from the first research objective will be a dependent variable, whereby poverty does not merely look from an economic aspect as it has three dimensions (MPI Research Team, 2015), representing the lack of physical infrastructures and its impacts (Adhi, 2009; UNDP, 2016). The independent variable consists of (i) access to physical infrastructures from home to the public facility, (ii) social capital value among households within village level that is labeled as social infrastructures, and (iii) spatial neighborhood effect between villages at the district. Social ties among households depict a function of the formation of social capital that might be able to mobilize both internal and external resources between individuals related to multiple memberships of certain institutions (Gibbs \& Coleman, 1990; Putnam, 2001; Wasserman \& Faust, 1994). In addition, according to an evidence review of public services in the United Kingdom, an inappropriate understanding of social networks and social capital might lead to wrong policy on how to deal with poverty through public services (Matthews \& Besemer, 2014).

As one of the regencies in East Java Province, Malang Regency has a $10.37 \%$ population below the poverty line (BPS, 2018a). Moreover, Jabung District is one of the districts with $29 \%$ of households identified as poor households (BPS, 2018b).

To be able to propose recommendations for poverty alleviation through spatial modelling, the study has three research objectives. First, measuring the poverty level at each village in the district from three poverty dimensions using the MPI. Second, calculating indices of Rate of Participation (RoP) and Density as a reflection of social relationships among villagers (Ari et al., 2017) implying Social Network Analysis (SNA). Third, finding significant variables of poverty level at the district using Spatial Regression Analysis.

Therefore, the research is an attempt to propose a holistic approach on the development of poverty alleviation method through integration between access to a public facility, social capital, and geographical position between villages that generally previous researches did it in separate ways that it might guide to misleading on targeting poverty policy.

\section{RESEARCH METHOD}

Jabung District in Malang Regency was selected as the research area because the district is categorized as one of the thirty-three districts with a high number of poor households in Malang Regency (BPS, 2018b). Primary data collection was designed using a questionnaire survey consisting of three parts, i.e. personal identity, attributes of the three dimensions of MPI, and attributes of community memberships into the existing community groups at the village.

The sample of respondents was 274 households distributed proportionally at each village whereby the district consists of 15 villages and 22.275 households with a total of 75.113 inhabitants (BPS, 2018b). Collecting data took about three weeks including 1 week for the interview and 2 weeks for field observation of the infrastructure data and secondary data. The secondary data were collected at each village government office and community health center in the district. The first period of data collection was carried out in July 2019, but due to the unpredicted global pandemic of Covid-19, a re-survey was conducted in July-August 2020 to ensure data validity.

\section{Analysis Method}

\section{a. Multidimensional Poverty Index (MPI)}

The first objective of the research is to measure the MPI covering the dimensions of (i) education, (ii) health, and (iii) living standards of each village, where the primary data were the main source for its measurement. A family is considered an impoverished household when its value of $C_{i}$ is $\geq 0.33$ (OPHDI, 2010). $C_{i}$ is labelled as the poverty index score of households $i$, which is equal to the sum of the total value of the whole number of households of its weights from indicator $\mathrm{i}\left(\mathrm{W}_{1 \ldots \mathrm{n}}\right)$ multiplied by 1 or 0 if respondents are included or not included in the indicator $1\left(\mathrm{I}_{1 \ldots \mathrm{n}}\right)$. 
Table 1. Dimension and Indicator of Multidimensional Poverty Index

\begin{tabular}{|c|c|c|}
\hline Dimensions & Description of Indicator & Weights \\
\hline \multirow[t]{2}{*}{ Health } & Nutrition: Child (<5 years) with malnutrition & $1 / 6=0.167$ \\
\hline & Child Mortality: Child ( $<5$ years) has died in the household within the last five years & $1 / 6=0.167$ \\
\hline \multirow[t]{2}{*}{ Education } & Educational Years: No household member has completed twelve years of schooling & $1 / 6=0.167$ \\
\hline & $\begin{array}{l}\text { School Attendance: Child of school-aged does not attend school until their age to complete } \\
12 \text { years of schooling }\end{array}$ & $1 / 6=0.167$ \\
\hline Living & Cooking Fuel: manure, firewood, or wood coal & $1 / 18=0.056$ \\
\hline \multirow[t]{5}{*}{ Standards } & $\begin{array}{l}\text { Sanitation: unimproved household's sanitation facility, or improved shared household's } \\
\text { sanitation }\end{array}$ & $1 / 18=0.056$ \\
\hline & $\begin{array}{l}\text { Drinking-Water: no access to safe drinking water, or access to safe drinking water with } \\
\text { roundtrip walking distance from home at about } 30 \text {-minute or longer }\end{array}$ & $1 / 18=0.056$ \\
\hline & Electricity: no access to electricity network & $1 / 18=0.056$ \\
\hline & Floor: a soil, gravel, or manure floor & $1 / 18=0.056$ \\
\hline & Assets: do not have a TV, radio, mobile phone, motorcycle, car. & $1 / 18=0.056$ \\
\hline
\end{tabular}

Table 1 displays the description for each dimension, and indicator of the MPI measurement based on the Indonesian situation, and for the weight for each indicator (UNDP, 2016). According to the Development Framework of Education (National Planning Board, 2016), each household member has to fulfil their study at a minimum level of senior high school at the age between 6 to 23 years old. Referring to the decree of the Indonesian Ministry of Health No.1995/Menkes/SK/XII/2010, the citizen will be defined as poor if in a family has one or more malnutrition and child mortality cases (KEMENKES RI, 2010). On the Technical Notes of Human Development Reports (HDR) (UNDP, 2016), the living standards comprise six indicators. A household is categorized as poor if (i) they use traditional cooking fuels such as firewood, (ii) have no private or even communal sanitation, (iii) do not have access to safe water network (such as acquire freshwater directly from well, spring, or river), (iv) do not get electricity supply, (v) use traditional floor material (such as dirt, sand land, animal manure), and (vi) have less than 1 asset of information, mobility, and livelihood. Referring to UNDP (2016), the weight is divided into three equally based on the number of dimensions. In more detail, $1 / 6$ is the weight for each indicator since the first and second dimensions consist of two indicators. Meanwhile, the weight of each indicator of the third dimension is $1 / 18$ since it has six indicators.

According to MPI Research Team (2015), MPI is measured by multiplying the percentage of the poor people or in other words, multiply the headcount ratio $(H)$ with the intensity of poverty $(A)$. In more detail, the headcount ratio $(H)$ is a ratio between the number of poor multidimensional individuals $(q)$ and a total number of population $(n)$. Value of $A$ is a ratio between sum up of poverty index score of households $i$ to $q$ (ci) and the number of poor multidimensional individuals. Then, the dimension contribution $k$ to poverty is expressed as a ratio between sum up $j$ member of $k$ of the sump up $c_{i j}$ from 1 to $q$ ( $\sum \mathrm{j} \in \mathrm{k}$ $\Sigma_{1}^{q} \mathrm{cij}$ ) and a total number of populations $(n)$, divided by the MPI value. According to the Module (MPI Research Team, 2015), the value of MPI's measurement can be differentiated into five levels, from very low $(<0.09)$, low $(0.09-0.18)$, medium (0.18-0.27), high (0.27-0.36), and very high (>0.36). The lower value of MPI means a better level of poverty or it shows lower level of poverty, and vice versa. Table 2 displays a detailed measurement of the indicator of each dimension in the MPI with binary choice (0 and 1 ).

b. Two Indices of Social Capital

The second research question is to measure two indices of social capital namely the RoP and density as the independent variable for the modelling (Ari et al., 2017; 2014; 2010). Referring to the SNA developed by Scott (2000) and Wasserman \& Faust (1994), the two indices are calculated by UCINET 6.3 as the analytical software. The type of data is called affiliation data of the respondents' memberships to the groups of community and is stored in the form of a matrix. Firstly, the data were stored as incidence matrix ( $n x m$ ) and then they had to be changed to adjacency matrix $(n \times n)$, as basic data on measuring a social relation between respondents at a village, where the two indices would represent their level of social capital. 
The RoP is a ratio between the sum of the number of memberships of each household to community groups $\left(x_{i j}\right)$ and a total number of respondents/head of households $(g)$ in a village area (Wasserman \& Faust, 1994). The value of the RoP is varied from one network to others, depending on the number of present groups of the community. The higher value of the RoP indicates the higher average of the total respondents in a certain area. The research classified the value of the RoP into three categories (low, medium, and high) to be able to compare the RoP among villages (Ari et al., 2017; 2014; 2010).

Table 2. Measurement of MPI Indicators

\begin{tabular}{|c|c|}
\hline Dimensions & Indicator \\
\hline \multicolumn{2}{|l|}{ Education } \\
\hline Years of & 1: less than senior high school level \\
\hline Education & 0 : senior high school and higher \\
\hline \multirow[t]{2}{*}{$\begin{array}{l}\text { School } \\
\text { attendance }\end{array}$} & $\begin{array}{l}\text { 1: do not attend the school between age 6-23 } \\
\text { years old }\end{array}$ \\
\hline & $\begin{array}{l}0: \text { attending the school between age } 6-23 \\
\text { years old }\end{array}$ \\
\hline \multicolumn{2}{|l|}{ Health } \\
\hline \multirow[t]{2}{*}{ Nutrition } & $\begin{array}{l}\text { 1: one or more cases of malnutrition in a } \\
\text { household }\end{array}$ \\
\hline & $0:$ no case of malnutrition in a household \\
\hline \multirow{3}{*}{$\begin{array}{l}\text { Child } \\
\text { Mortality }\end{array}$} & 1: one or more cases of child mortality in a \\
\hline & household \\
\hline & $0:$ no case of child mortality in a household \\
\hline \multicolumn{2}{|c|}{ Standard of Living } \\
\hline Cooking & 1: using firewood for cooking \\
\hline Fuel & $\begin{array}{l}\text { 0: using Liquid Propane Gas (LPG), Biogas and } \\
\text { Electricity }\end{array}$ \\
\hline \multirow[t]{2}{*}{ Sanitation } & $\begin{array}{l}\text { 1: no sanitation, jointly sanitation, and } \\
\text { communal sanitation }\end{array}$ \\
\hline & $0:$ personal sanitation \\
\hline \multirow[t]{2}{*}{$\begin{array}{l}\text { Drinking- } \\
\text { Water }\end{array}$} & $\begin{array}{l}\text { 1: using no piped drinking water (river, well, } \\
\text { spring) }\end{array}$ \\
\hline & $\begin{array}{l}\text { 0: using piping drinking water (PDAM, } \\
\text { HIPPAM) }\end{array}$ \\
\hline \multirow[t]{2}{*}{ Electricity } & 1: no access to electricity \\
\hline & $0:$ have access to electricity \\
\hline \multirow[t]{2}{*}{ Floor } & $\begin{array}{l}\text { 1: infeasible floor pavement (soil, sand-land, } \\
\text { animal feces) }\end{array}$ \\
\hline & 0 : feasible floor pavement \\
\hline \multirow[t]{2}{*}{ Assets } & $\begin{array}{l}\text { 1: having }<1 \text { of information, mobility, } \\
\text { livelihood assets }\end{array}$ \\
\hline & $\begin{array}{l}0 \text { : having a minimum } 1 \text { of the information } \\
\text { assets, and } 1 \text { of mobility and livelihood } \\
\text { assets }\end{array}$ \\
\hline
\end{tabular}

Density is used to identify how dense relationship among village members within a network (Scott, 2000; Wasserman \& Faust, 1994), which is the ratio of the summation of the connected number of the respondents $i$ to $j\left(\sum_{\mathrm{i}}^{\mathrm{g}}=1 \sum_{\mathrm{i}}^{\mathrm{g}}=1 \mathrm{x}_{\mathrm{ij}}^{\mathrm{N}}\right)$ multiplied by the number of respondents $(g)$ and the number of isolated respondents $(g-1)$. Isolated respondents were heads of households with no affiliation with others since they did not join in any kind of community group within a certain village. The value of the density is between 01 (Scott, 2000; Wasserman \& Faust, 1994), and it will classify into three levels similar to the RoP (Ari et al., 2017; 2014; 2010). The higher value of density of an area defines the deeper social relations amongst respondents within the area.

According to Scott (2000), the data type for the SNA is the affiliations formed through links among people within each village from their membership in existing community group. Such community groups consisted of (i) male quran recitation, (ii) female quran recitation, (iii) quran recitation, and (iv) youth group. The first three groups were purely religious activity amongst Moslems for having a better understanding about their religion. Meanwhile, the last group was a communal activity of villagers related to their daily activity such as environmental cleanliness and annual independent day festival.

c. Spatial Regression Analysis

The Geographic Data Analysis (GeoDa) was used to identify spatial data analysis (Anselin, 1988; Griffith \& Anselin, 1989) to address the third research question. The space concept was applied through a weight matrix, which described the position of the location of the area of connectivity in a set of data. In the study, neighbors in the district were described by the Queen weight matrix that determined a neighbor of the village as an adjacent edge or vertex. The characteristics of weights matrices were displayed in a connectivity histogram. Each bar explained the frequency of each neighbor in Jabung District.

Spatial autocorrelation (SA) denotes the positive and negative of a variable correlation with itself in spatial location. The positive value describes similar spatial clusters of high-high or low-low, meanwhile, the negative indicates different values of spatial outliers of high-low or low-high. The research calculated the SA by putting the values of the MPI as variable and the Queen weight matrix as spatial settings. The positive SA present during high values of the MPI correlated with high values of the neighboring, and vice versa (Anselin, 1995).

Moran Scatter Plot displays the type and strong point of the SA in a distribution of data, where the slope depicts the Moran's I value as observing of global clustering of the SA in a set of data. The scatter plot consists of four quadrants that display the 
relationship between the MPI value of a village to its neighbors with the positive and negative SA (Yuriantari et al, 2017).

The presence or absence of significant or outlier spatial clusters for each position is specified by the Local Indicators of Spatial Association (LISA). In particular, the maps of LISA are effective for evaluating the proposition of spatial arbitrariness and recognize local hot spots.

\section{RESULT AND DISCUSSION}

\section{Socioeconomic Characteristic}

The following seven tables indicate general characteristics of education, health, and living standards dimensions at each village in the district from the secondary data compilation.

Table 3. Educational Attainment of Household

\begin{tabular}{lcccc}
\hline Village & $\begin{array}{c}\text { Not } \\
\text { Complete } \\
\text { Elemen- } \\
\text { tary } \\
\text { School }\end{array}$ & $\begin{array}{c}\text { Elemen- } \\
\text { tary } \\
\text { School }\end{array}$ & $\begin{array}{c}\text { Junior } \\
\text { High } \\
\text { School }\end{array}$ & $\begin{array}{c}\text { Senior } \\
\text { High } \\
\text { School }\end{array}$ \\
\hline Sidomulyo & $\ldots \ldots \ldots \ldots \ldots \ldots \ldots \ldots \ldots \ldots \ldots \ldots \ldots \ldots \ldots \ldots \ldots$ \\
Kenongo & 20 & 67 & 3 & 10 \\
Kemiri & 34 & 62 & 0 & 4 \\
Gading Kembar & 20 & 75 & 5 & 0 \\
Jabung & 3 & 82 & 10 & 5 \\
Gunungjati & 2 & 87 & 11 & 0 \\
Ngadirejo & 7 & 89 & 0 & 4 \\
Argosari & 63 & 34 & 3 & 0 \\
Pandansari Lor & 0 & 95 & 0 & 5 \\
Slamparejo & 3 & 86 & 0 & 11 \\
Taji & 24 & 68 & 5 & 3 \\
Kemantren & 8 & 84 & 8 & 0 \\
Sukolilo & 17 & 71 & 5 & 5 \\
Sukopuro & 20 & 43 & 2 & 33 \\
Sidorejo & 21 & 60 & 10 & 8 \\
\hline & 16 & 57 & 3 & 24 \\
\hline
\end{tabular}

Table 3 illustrates the educational background of the resident within four categories: (i) not completing elementary school, (i) elementary school, (iii) junior high school, and (iv) senior high school. The majority level of education was elementary school, with the highest percentage in Argosari Village (93\%). The residents of Sukolilo Village had the highest percentage of high school graduates (33\%). Meanwhile, the highest number of residents who did not complete elementary school was in Ngadirejo Village. Referring to National Planning Board (2016), the results might imply that to avoid poverty minimum level of educational background should be no less than high school graduates.
Table 4 describes cooking fuel types used by households covering firewood, Liquid Propane Gas (LPG), Biogas, and Electricity. The majority of households used firewood $(50,5 \%)$, while biogas was the most rarely used cooking fuel $(1 \%)$. The highest firewood users lived in Taji Village (91\%). Then, the second-largest type of cooking fuel was LPG (40\%). The majority of households who used LPG lived in Sidorejo Village (91\%). Referring to Technical Notes HDR 2016 (UNDP, 2016), the higher the number of residents who use firewood, the higher the poverty level of the area.

Table 4. Household Fuel Use of Cooking

\begin{tabular}{lcccc}
\hline Village & $\begin{array}{c}\text { Fire- } \\
\text { wood }\end{array}$ & $\begin{array}{c}\text { Liquid } \\
\text { Propane } \\
\text { Gas }\end{array}$ & Biogas & $\begin{array}{c}\text { No } \\
\text { Cooking }\end{array}$ \\
\hline Sidomulyo & $\ldots \ldots \ldots \ldots \ldots \ldots \ldots \ldots \ldots \ldots \ldots \ldots \ldots \ldots \ldots \ldots \ldots \ldots \ldots \ldots \ldots \ldots$ & $\% \ldots \ldots \ldots$ \\
Kenongo & 67 & 30 & 1 & 2 \\
Kemiri & 17 & 83 & 0 & 0 \\
Gading Kembar & 63 & 34 & 0 & 3 \\
Jabung & 68 & 29 & 0 & 3 \\
Gunungjati & 60 & 35 & 0 & 5 \\
Ngadirejo & 93 & 7 & 0 & 0 \\
Argosari & 30 & 70 & 0 & 0 \\
Pandansari Lor & 78 & 21 & 0 & 1 \\
Slamparejo & 59 & 39 & 1 & 1 \\
Taji & 20 & 77 & 0 & 3 \\
Kemantren & 91 & 9 & 0 & 0 \\
Sukolilo & 50 & 43 & 0 & 7 \\
Sukopuro & 26 & 72 & 0 & 2 \\
Sidorejo & 39 & 60 & 0 & 1 \\
\hline
\end{tabular}

There was four types of sanitation, i.e. personal sanitation, no sanitation, jointly sanitation, and communal sanitation (Table 5). Based on secondary data, $50 \%$ of residents of the district used personal sanitation, while communal sanitation was the lowest type used by the residents ( $5 \%)$. Villages with the highest number of personal, sharing, communal, and no sanitation were Sukolilo (82\%), Gunungjati (39\%), Argosari (44\%), and Pandansarilor (56\%), respectively. On one hand, residents characterized by joint, communal, and no sanitation increase the index of multidimensional poverty, and on the other hand, personal sanitation users are not classified as poor people, which then will not increase the poverty index (Research Team MPI, 2015).

Table 6 displays three types of access to drinking water in the district, which consisted of wells (without pipeline), HIPPAM (community-based water management using simple pipeline connection), and PDAM (local government drinking water company). 
Based on the observation survey, the HIPPAM users were spread in ten villages. In the village of Sidomulyo, Kenongo, Pandansarilor, Taji, and Sukopuro, $100 \%$ of the households got access to clean water from HIPPAM service. PDAM service was only available in three villages, i.e. Gadingkembar, Kemantren, and Sukolilo.

Table 5. Household Sanitation Use

\begin{tabular}{lcccc}
\hline Village & Personal & Without & Sharing & $\begin{array}{r}\text { Com- } \\
\text { munal }\end{array}$ \\
\hline Sidomulyo & $\ldots \ldots \ldots \ldots \ldots \ldots \ldots$ & $\% \ldots \ldots \ldots \ldots \ldots \ldots$ \\
Kenongo & 35 & 43 & 12 & 10 \\
Kemiri & 44 & 50 & 4 & 2 \\
Gading Kembar & 77 & 10 & 11 & 2 \\
Jabung & 64 & 23 & 12 & 1 \\
Gunungjati & 58 & 0 & 29 & 13 \\
Ngadirejo & 61 & 0 & 39 & 0 \\
Argosari & 50 & 40 & 9 & 1 \\
Pandansari Lor & 25 & 2 & 29 & 44 \\
Slamparejo & 32 & 56 & 12 & 0 \\
Taji & 67 & 13 & 18 & 2 \\
Kemantren & 60 & 38 & 2 & 0 \\
Sukolilo & 73 & 9 & 17 & 1 \\
Sukopuro & 82 & 3 & 13 & 2 \\
Sidorejo & 66 & 19 & 10 & 5 \\
\hline
\end{tabular}

Table 6. Household Drinking-Water Use

\begin{tabular}{lrrr}
\hline Village & Well & HIPPAM & PDAM \\
\hline & $\ldots \ldots \ldots \ldots \ldots \ldots \ldots \ldots$ & $\% \ldots \ldots \ldots \ldots \ldots . \ldots$ \\
Sidomulyo & 0 & 100 & 0 \\
Kenongo & 0 & 100 & 0 \\
Kemiri & 18 & 82 & 0 \\
Gading Kembar & 29 & 42 & 29 \\
Jabung & 100 & 0 & 0 \\
Gunungjati & 100 & 0 & 0 \\
Ngadirejo & 100 & 0 & 0 \\
Argosari & 50 & 50 & 0 \\
Pandansari Lor & 0 & 100 & 0 \\
Slamparejo & 33 & 67 & 0 \\
Taji & 0 & 100 & 0 \\
Kemantren & 90 & 5 & 5 \\
Sukolilo & 65 & 0 & 35 \\
Sukopuro & 0 & 100 & 0 \\
Sidorejo & 100 & 0 & 100 \\
\hline
\end{tabular}

Access to electricity for each household in the study area consisted of (i) personal, (ii) sharing, and (iii) no electricity (Table 7) where the electricity was provided by the State Electricity Company. The first type means households who were registered as customers and had 'direct' electricity connection to their houses. The second one is households with an electricity connection via a neighbor who was a customer of the Electricity Company. Then, the last type is households without access to electricity. The number of households according to the types was $4,087,2,313$, and 12, respectively. Households with no access to electricity were located in six villages, i.e. Sidomulyo, Jabung, Argosari, Pandansarilor, Slamparejo, and Sukolilo. In addition, the majority of households with sharing electricity lived in Jabung Village, as many as 296 households. The number of households in the second and third types might increase poverty level due to the basic necessity of electricity for supporting daily activity.

Table 7. Household Access to Electricity

\begin{tabular}{lccc}
\hline Village & Sharing & Private & $\begin{array}{c}\text { No } \\
\text { Electricity }\end{array}$ \\
\hline Sidomulyo & $\ldots \ldots \ldots \ldots \ldots \ldots \ldots \ldots \ldots \ldots \ldots \ldots \ldots \ldots \ldots \ldots \ldots \ldots$ & $\% \ldots \ldots \ldots$ \\
Kenongo & 24 & 76 & 0 \\
Kemiri & 37 & 63 & 0 \\
Gading Kembar & 55 & 45 & 0 \\
Jabung & 48 & 52 & 0 \\
Gunungjati & 29 & 71 & 0 \\
Ngadirejo & 4 & 96 & 0 \\
Argosari & 20 & 80 & 0 \\
Pandansari Lor & 18 & 82 & 1 \\
Slamparejo & 49 & 50 & 1 \\
Taji & 37 & 62 & 0 \\
Kemantren & 16 & 84 & 0 \\
Sukolilo & 36 & 64 & 0 \\
Sukopuro & 54 & 46 & 0 \\
Sidorejo & 43 & 57 & 0 \\
\hline
\end{tabular}

Table 8. Household Floor Type Use

\begin{tabular}{lccrcc}
\hline Village & Dirt & Cement & Tile & $\begin{array}{c}\text { Cera- } \\
\text { mic }\end{array}$ & Wood \\
\hline Sidomulyo & $\ldots \ldots \ldots, \ldots \ldots \ldots \ldots$ & $\%$ & $\ldots \ldots \ldots \ldots \ldots \ldots \ldots$ \\
Kenongo & 55 & 29 & 3 & 13 & 0 \\
Kemiri & 29 & 8 & 42 & 12 & 0 \\
Gading Kembar & 61 & 28 & 1 & 8 & 0 \\
Jabung & 58 & 12 & 17 & 34 & 0 \\
Gunungjati & 51 & 22 & 0 & 5 & 0 \\
Ngadirejo & 63 & 11 & 8 & 21 & 0 \\
Argosari & 36 & 20 & 0 & 21 & 0 \\
Pandansari Lor & 67 & 19 & 0 & 12 & 0 \\
Slamparejo & 45 & 28 & 1 & 22 & 0 \\
Taji & 21 & 13 & 5 & 0 & 0 \\
Kemantren & 51 & 18 & 8 & 16 & 0 \\
Sukolilo & 34 & 30 & 10 & 33 & 0 \\
Sukopuro & 26 & 39 & 5 & 36 & 0 \\
Sidorejo & 18 & 38 & 16 & 31 & 0 \\
\hline
\end{tabular}

There were five types of floors of the houses: dirt, cement, tile, ceramics, and wood (Table 8). There were nine villages where more than $40 \%$ of their households still had dirt as the floor, covering 3,436 households in total. Kemiri Village had the highest number of households with a dirt floor, while Taji 
Village had the lowest number of it. It means that a higher number of households with dirt floors might heighten MPI value.

Table 9. Household Access to Assets Use

\begin{tabular}{lccc}
\hline Village & $\begin{array}{c}\text { Access to } \\
\text { Informa- } \\
\text { tion }\end{array}$ & $\begin{array}{c}\text { Mobility } \\
\text { Support }\end{array}$ & $\begin{array}{c}\text { Livelihood } \\
\text { Support }\end{array}$ \\
\hline Sidomulyo & $\ldots \ldots \ldots \ldots \ldots \ldots \ldots \ldots \ldots \ldots \ldots \ldots \ldots \ldots \ldots \ldots \ldots \ldots \ldots$ \\
Kenongo & 100 & 100 & 9 \\
Kemiri & 100 & 100 & 0 \\
Gading Kembar & 72 & 49 & 4 \\
Jabung & 89 & 77 & 36 \\
Gunungjati & 80 & 77 & 7 \\
Ngadirejo & 77 & 31 & 8 \\
Argosari & 78 & 22 & 11 \\
Pandansari Lor & 64 & 71 & 21 \\
Slamparejo & 63 & 50 & 19 \\
Taji & 55 & 44 & 5 \\
Kemantren & 100 & 60 & 100 \\
Sukolilo & 98 & 97 & 7 \\
Sukopuro & 85 & 75 & 65 \\
Sidorejo & 78 & 69 & 28 \\
\hline
\end{tabular}

Table 9 shows three components of household asset: (i) access of information: household with one of the communication tools, such as television, radio, telephone/handphone, and laptop/computer; (ii) mobility support: household with one tool to facilitate mobility for human or goods such as truck, car, motorcycle, bike, animal train and motorboat; and (iii) livelihood support: household with one thing to support livelihoods such as refrigerator, horse, cow, sheep, goat, chicken, soil, garden or rice field.

In general, households at each village in Jabung District had over $50 \%$ of the asset of access to information. Under $50 \%$ of the households in three villages, i.e. Gunungjati, Ngadirejo, and Slamparejo had the asset of mobility support. Only two villages, i.e. Taji and Sukolilo, had the asset of livelihood support, while the rest did not. Slamparejo Village had the lowest number of households with a total of three assets, while Taji Village had the highest one. Since the better availability of the assets might reflect the better support for the villagers' daily activity, it may infer that households in the district do not have sufficient assets to ease their livelihood.

Table 10 illustrates the results of the poverty level of the MPI measurement, where the value and classification of poverty level at each village are described at the second and third columns, and its contribution of deprivation of each dimension is put at the last three columns.

It is identified that among five poverty levels (MPI Research Team, 2015), there were four poverty levels in Jabung District: very low, low, medium, and high level, and they occurred at 3, 2, 5, 5 number of villages, respectively. Moreover, Table 10 illustrates that the village of Kemiri, Jabung, Gunungjati, Slamparejo, and Taji had higher MPI values than others in Jabung District. Interestingly, the poorest village in the district was in Jabung village with an MPI value $=0.34$ although it is also the capital of the district. In the meantime, the most wealthy village indicated by the lowest value of MPI was in Sukolilo Village (0.05). The higher MPI value indicates the more cases of poverty found in households in the village.

Table 10. Value of Multiple Poverty Index

\begin{tabular}{|c|c|c|c|c|c|}
\hline \multirow{2}{*}{ Villages } & \multirow{2}{*}{ MPI } & \multirow{2}{*}{ Classification } & \multicolumn{3}{|c|}{ Deprivation Contribution to Total Poverty } \\
\hline & & & Education & Health & Living Standards \\
\hline & & & & $\ldots . \%$. & \\
\hline Sidomulyo & 0.10 & Low & 44 & 0 & 56 \\
\hline Kenongo & 0.16 & Low & 51 & 11 & 37 \\
\hline Kemiri & 0.29 & High & 50 & 0 & 50 \\
\hline Gading Kembar & 0.20 & Medium & 57 & 0 & 43 \\
\hline Jabung & 0.34 & High & 55 & 0 & 45 \\
\hline Gunungjati & 0.29 & High & 43 & 0 & 57 \\
\hline Ngadirejo & 0.19 & Medium & 59 & 0 & 41 \\
\hline Argosari & 0.22 & Medium & 48 & 4 & 48 \\
\hline Pandansari Lor & 0.18 & Medium & 44 & 0 & 56 \\
\hline Slamparejo & 0.29 & High & 60 & 0 & 40 \\
\hline Taji & 0.31 & High & 64 & 0 & 36 \\
\hline Kemantren & 0.05 & Very Low & 49 & 0 & 51 \\
\hline Sukolilo & 0.04 & Very Low & 49 & 25 & 26 \\
\hline Sukopuro & 0.23 & Medium & 46 & 0 & 54 \\
\hline Sidorejo & 0.05 & Very Low & 78 & 0 & 22 \\
\hline
\end{tabular}




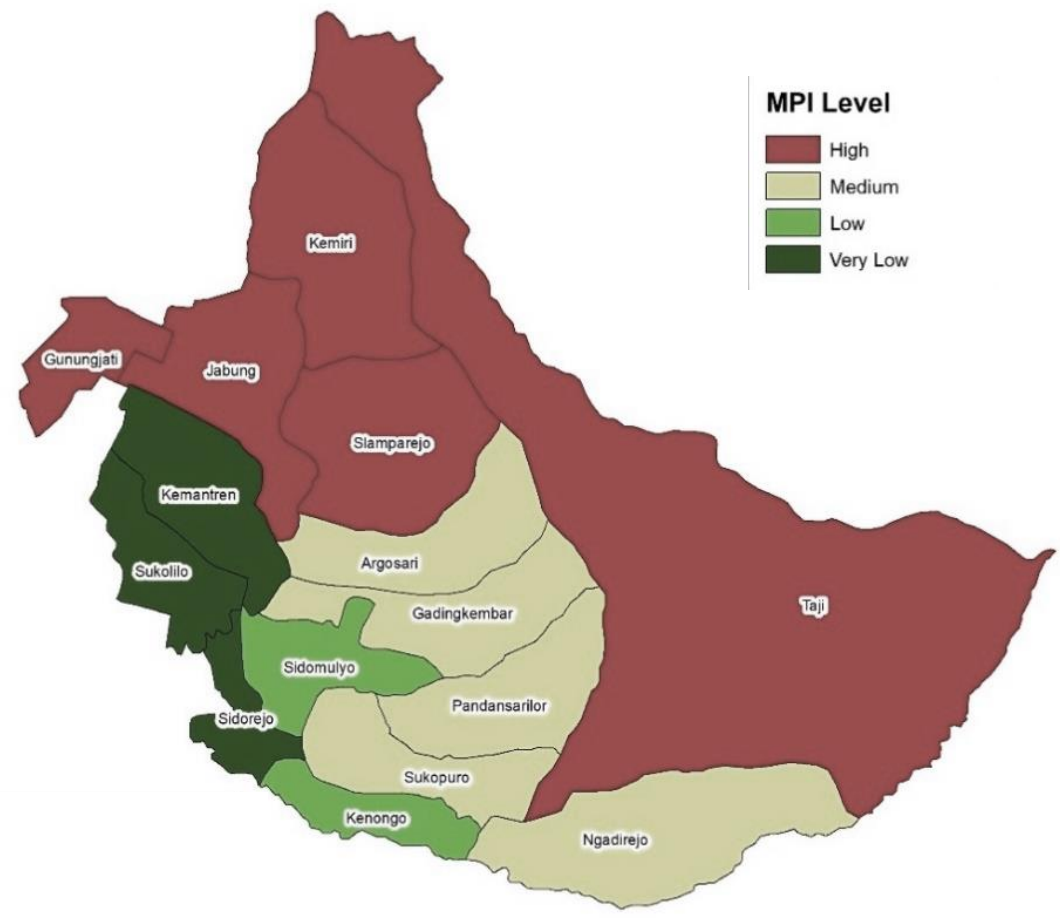

Figure 1. MPI level map of Jabung District

Based on MPI Data in 2017 (Humanitarian Data Exchange, 2020), the MPI of East Java Province was 0.011 , slightly lower than the MPI of Indonesia at about 0.014 . We may see from Table 10 that on average, villages in Jabung District Malang Regency had a higher level of MPI value than the East Java province. Even when compared to the lowest value of MPI at Sukolilo village, the value of the village was still higher than the province. In detail, the deprivation contribution of each dimension to total poverty of East Java Province was $30.51 \%, 33.11 \%$, and $36.38 \%$ for education, health and living standards, respectively. If those are compared to the result of Jabung District, the district's poverty was contributed by dimensions of the Education and Living Standards, since the dimension of Health indicated better result at about 0 $25 \%$. In addition, detailed information on each dimension's contribution is valuable for figuring the deprivation structure of the district, so that it can be continued as a policy of ending poverty. Education and Living Standards affected the values of the MPI at all villages in Jabung District. Meanwhile, the Health dimension affected the values of the MPI in three out of fifteen villages, namely Kenongo, Argosari, and
Sukolilo. It means that the poverty alleviation program in Jabung District can take two dimensions, i.e. education and living standards, into consideration.

Figure 1 describes a map of the MPI level per village for the whole Jabung District. The five villages with high poverty levels are geographically neighbors, along with the other five villages with medium poverty levels. It is quite different from the village with low and very low poverty levels, where the villages with high poverty levels tend to form a kind of 'geographic' cluster than the villages characterized by a lower level of poverty. The map gives an interesting fact that it can be assumed or even questioned whether poverty level and geographic areas have a connection to each other. Therefore, measurement of the MPI was continued with the second and third research questions for having a better understanding of the poverty occurrence.

\section{Social Capital}

In general, The Rate of Participation (RoP) illustrates the involvement rates of the community members to the present local institutional at a network (Scott, 2000; Wasserman \& Faust, 1994) that will 
describe the average participation of the villagers. Then, the density describes a level of relationship between residents within a network ( $\underline{\text { Scott, 2000; }}$ Wasserman \& Faust, 1994) that might give a significant difference of flowing of information or resource among residents in the village.

As displayed in Table 11, every village had a similar number of groups at about 4 types of local institution. There were 4 villages classified as having high RoP, i.e. Kenongo, Kemantren, Sukolilo, and Sidorejo, where the average households had an affiliation to 23 types of the local institution. Then, 11 of 15 villages had a medium level of the RoP. On average, households had an affiliation to 1-2 out of four types of local institution.

Table 11. RoP for Each Village in Jabung District

\begin{tabular}{lccc}
\hline Village & Value & $\begin{array}{c}\text { No of } \\
\text { Institution }\end{array}$ & Level \\
\hline Sidomulyo & 2.40 & 4 & Medium \\
Kenongo & 2.76 & 4 & High \\
Kemiri & 2.00 & 4 & Medium \\
Gading Kembar & 2.20 & 4 & Medium \\
Jabung & 1.80 & 4 & Medium \\
Gunungjati & 2.15 & 4 & Medium \\
Ngadirejo & 2.33 & 4 & Medium \\
Argosari & 2.42 & 4 & Medium \\
Pandansari Lor & 2.50 & 4 & Medium \\
Slamparejo & 2.00 & 4 & Medium \\
Taji & 2.10 & 4 & Medium \\
Kemantren & 2.80 & 4 & High \\
Sukolilo & 2.75 & 4 & High \\
Sukopuro & 2.21 & 4 & Medium \\
Sidorejo & 2.84 & 4 & High \\
\hline
\end{tabular}

Table 12 depicts three levels of density for each village: high (2 villages), medium (5 villages), and low (8 villages). In terms of social networks, when an actor has a connection to others in the network, it might open the happening of the information and resources flows. Hence, the higher density assumes that the community might have a higher possibility to mobilize both local and extra-local 'energy' within the network (Putnam, 2001).

A village with a higher level of the RoP indicates that the greater number of villagers become members of the greater number of local institutions. And, a village with a higher level of density specifies a deeper social relationship among its community members. The measurement of the two indices of social capital in the level of village indicates that generally social capital of the community in the district was not so strong. It might give an impact on their ability to utilize their internal and external information as well resources for their community's needs.

Table 12. Density for Each Village in Jabung District

\begin{tabular}{lcc}
\hline Village & Value & Level \\
\hline Sidomulyo & 0.30 & Low \\
Kenongo & 1.00 & High \\
Kemiri & 0.44 & Medium \\
Gading Kembar & 0.44 & Medium \\
Jabung & 0.23 & Low \\
Gunungjati & 0.64 & Medium \\
Ngadirejo & 0.38 & Medium \\
Argosari & 0.22 & Low \\
Pandansari Lor & 0.18 & Low \\
Slamparejo & 0.31 & Low \\
Taji & 0.90 & High \\
Kemantren & 0.41 & Medium \\
Sukolilo & 0.41 & Low \\
Sukopuro & 0.24 & Low \\
Sidorejo & 0.30 & Low \\
\hline
\end{tabular}

The research assumes that the two indices of social capital might be useful for the villagers to deal with their multidimensional poverty. Hence, the indices were placed in the model as independent 'social' variables along with travel time to physical infrastructures as the independent 'physical' variables. In other words, the RoP and density are the independent variables in conjunction with the geographical distance of the three-physical infrastructure in Spatial Regression Analysis.

\section{Spatial Distribution of Poverty}

In the spatial regression analysis, firstly Queen Weight Matrix was used to define neighbors of each village in the district. The characteristic of the weight matrix is plotted in Table 13 about the Connectivity Histogram that displays the number of neighbors of each village and its frequency. The minimum number of neighbors (one village with one neighbor) is signed by the blue color bar that occurs at one village. The orange color bar displays the village with the maximum number of neighbors (one village with 8 neighbors). Four villages have three neighbors and the other four villages have five neighbors indicated by the light green and pink bar. Hence, number of neighbors in the district is varied from each other. The nearest position can have similar characters (in this case is poverty) to the distant ones (Anselin, 1995) Then, to differentiate the MPI correlation, the value of MPI and contiguity matrix was used as input at the SA. The Moran Scatter plot visualizes the type and strength of the SA (Figure 2). The slope displays 
positive autocorrelation of the village with its neighbors through the MPI values, which are HighHigh and Low-Low.

Table 13. Connectivity Neighbors

\begin{tabular}{|c|c|c|}
\hline $\begin{array}{l}\text { Number } \\
\text { of Neigh- } \\
\text { bors }\end{array}$ & $\begin{array}{c}\text { Frequ- } \\
\text { ency }\end{array}$ & Villages \\
\hline 1 & 1 & Gunungjati \\
\hline 2 & 0 & - \\
\hline 3 & 4 & Kemiri, Sukolilo, Kenongo, Ngadirejo \\
\hline 4 & 3 & Slamparejo, Sidorejo, Pandansarilor \\
\hline 5 & 4 & $\begin{array}{l}\text { Kemantren, Argosari, Gadingkembar, } \\
\text { Jabung }\end{array}$ \\
\hline 6 & 2 & Sukopuro, Taji \\
\hline 7 & 1 & Sidomulyo \\
\hline
\end{tabular}

Figure 3 illustrates a detail of substantial spatial clusters for every village in the district, consisting of two types. First, the cluster of Low-Low occurred at three villages (Sukolilo, Sidorejo, and Sidomulyo) and three non-poor villages (characterized with the low value of MPI), where they are situated near each other geographically. It means that there is a tendency of forming clusters between the non-poor villages. Second, the cluster of High-High happened at two villages (Slamparejo and Kemiri) and two poor villages (indicated with the high value of MPI) which are geographically neighbors. Although the number of villages is slightly fewer than the first type of cluster, it seems that there is also a tendency to form a cluster between similar characteristics between poor villages which are physically adjacent.

Along with the first geography's law of Tobler (Anselin, 1995), the result of research reveals that neighboring villages have higher similarity in values than the detached ones. Therefore, we might infer that there is a tendency for both poor and non-poor adjacent villages to form a cluster to each other due to their structure of spatial. Policy recommendations of poverty alleviation for the district that might be proposed are as follows. First, prioritize development to the poor villages which form a spatial cluster to each other, so that the negative value might lessen and being contained within the existing villages. Secondly, maintain the dynamics of development of the nonpoor villages, in particular for the clustered adjacent villages. In the long term, it might disseminate the positive value to other villages who are physically neighbors to each other or not.

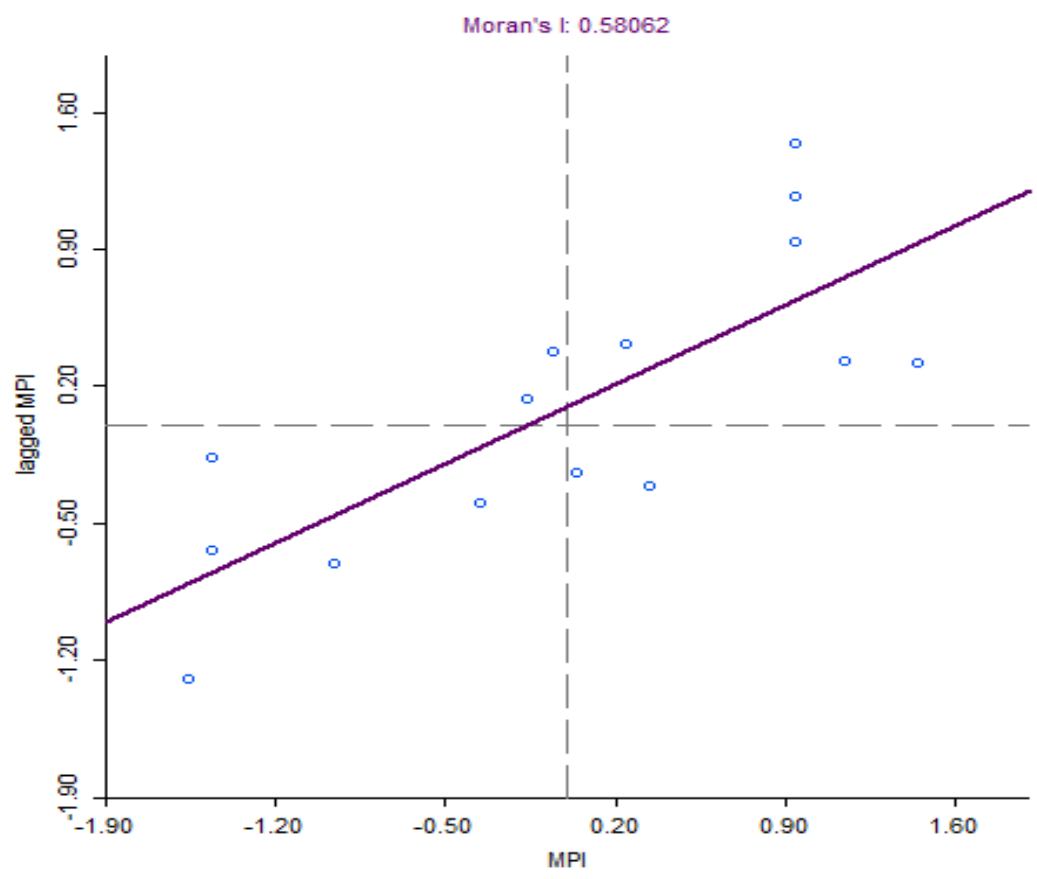

Figure 2. Moran scatter plot result 


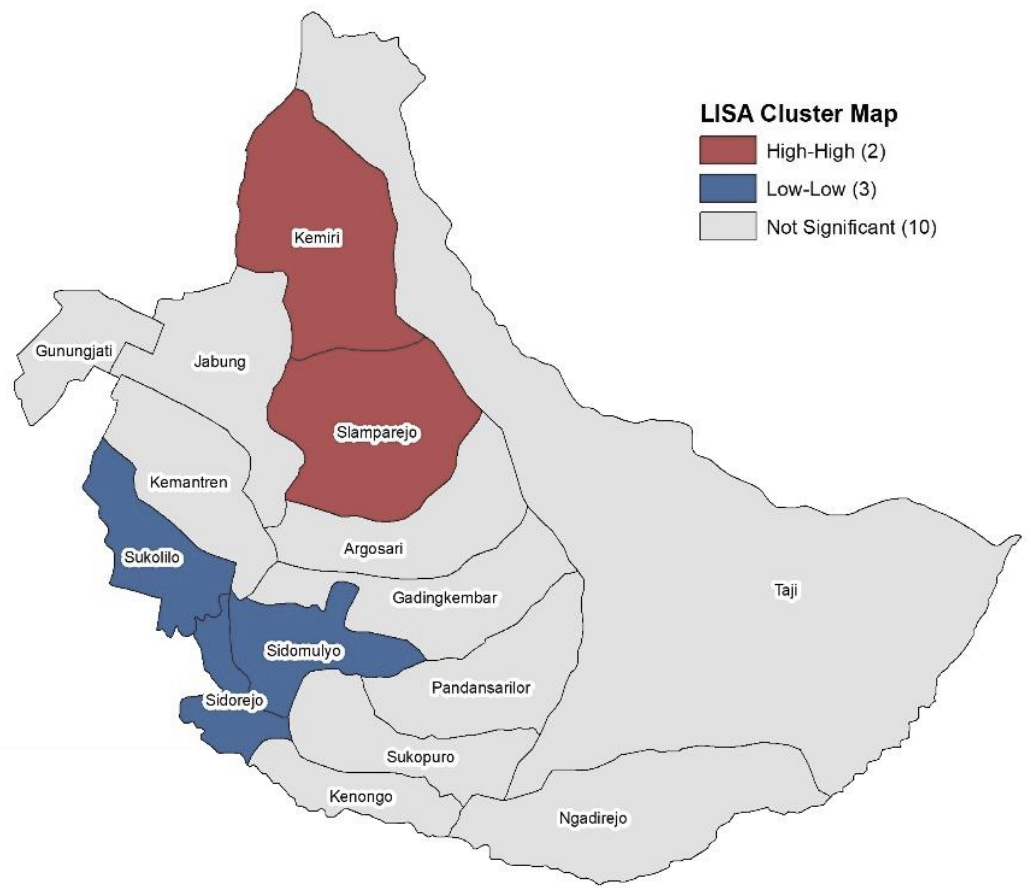

Figure 3. LISA cluster map of Jabung District

The first step of spatial regression analysis was operating the OLS model. At the first ordinary least square regression, the five independent variables were (i) two social capital indices comprise Rate of Participation (RoP) (X1), Density (X2), and (ii) three physical access described as travel time $(T T)$ in minutes by motorbike mode consisting of $\Pi T$ to Senior High School (X3), TT to Hospital (X4), TT to District Center of Jabung (X5). The fifth independent variable was hypothesized to have a significant influence on the dependent variable of the MPI value. Except for the independent variable of $\mathrm{X} 1$ which accepted $\mathrm{HO}$, the others were rejected. The following model displays the final result of the Spatial Regression Analysis.

$\hat{y}=0.64+0.38 \sum_{j=1}^{n} i \neq j$ Wijy $-0.22 \mathrm{X} 1$

in which $\hat{y}$ is Multidimensional Poverty Index (MPI) value, Wy is Weight matric, and X1 is Rate of Participation (RoP).

The negative value of the independent variable of the RoP was designed as the one significant independent variable where the stronger average participation of the community members might give a positive impact to lessen the poverty of the district, and vice versa. It means that fostering community participation will widen their opportunity to escape from poverty, since they can utilize their strong social connections between residents to develop welfare for the community (Gibbs \& Coleman, 1990; Ostrom \& Ahn, 2003; Putnam, 2001; Ari et al., 2017, 2019, 2020). In the model, the positive value of the weight matrix describes that physical nearness between villages has a significant influence on each other. Once a poor village has a closer distance to another poor village, they might have a higher possibility of having a higher level of poverty, and vice versa. As a whole, the model suggests that it is important to notice that the poverty action plan will face a bigger challenge to the poor clustered villages so that both physical as well social infrastructures development need to be tackled together.

\section{Research Implication}

Measurement of the MPI indicates that generally poverty in each village was contributed by the dimension of Education and Living Standards. Then, 
the measurement of the two indices of social capital illustrates that the community did not have a strong social relationship that might bring them to have a better possibility to utilize their both internal and external resources. Hence, when the results were put together, the community still did not understand the bad impact of not having level of education according to the national standard since they had a common situation with other community members. A similar reason might happen toward the Living Standards dimension, where the impact was they might feel fine with their current assets to support their daily activity. It was different from the dimension of health. It seemed that the health program reached them effectively, so the contribution of deprivation of the health dimension was very low even though there were three villages with a quite significant percentage of contribution of deprivation of health dimension. Moreover, referring to Ari, et al. (2020), education level can be one of the causes of poverty because of the powerlessness of the community, as shown from the result of the two indices of social capital where most community members did not have a strong social relationship to change their preference regarding the importance of education level for their welfare. As a projection, if their understanding remains the same as the previous time, it might lead to endless problems of poverty, and the community might find it difficult to live in prosperity.

Results of the spatial regression analysis reflect that the level of community participation had a significant effect on poverty in the Jabung District. In addition, Yamin \& Dartanto (2016) that the positive impact of social capital will increase better access to information for the people, so they might have opportunities to gain knowledge that widen their perspective on how to develop their welfare.

One thing that needs to be considered in the MPI poverty model that has been carried out through spatial regression analysis is the presence of spatial factors or neighboring factors that also have a significant influence on poverty. It can be seen in the LISA map results which show high-high and low-low clusters. This means that solving the problem of poverty is not only done in the one area with the worst MPI value, but the MPI in neighboring villages also needs to be paid attention to.

Based on the measurement of poverty through MPI, it can be seen that the cause of poverty in the district is not only related to weak economic conditions, but also to the dimension of low education and low social capital conditions. According to Malang Regency RPJMD 2016-2021 policies, creating jobs and reducing unemployment is indispensable to the poverty elimination action plan. It means that recommendations can be given for the government to consider the education factor and community empowerment through attractive programs in local community institutions so that people might actively contribute in institutions as a place or space to exchange both internal and external information as well resources.

\section{CONCLUSION AND SUGGESTION}

The MPI measurement indicates that poverty that occurs in the Jabung District was a result of the contribution of deprivation of Education and Living Standards dimensions since the majority of deprivation contribution of Health dimension was zero. Hence, from the point of view of MPI, policy recommendations on ending poverty should focus upon the development of Education and Living Standards dimensions. At the level of the village, the five villages with high MPI value that should become targeted areas on dealing with poverty alleviation consisted of Jabung, Taji, Kemiri, Gunungjati, and Slamparejo.

Furthermore, the research also indicates that there was a correlation between the value of MPI in Jabung district and the neighbor spatial condition shown through the LISA map. It denotes that if a poor village has the nearest physical border with one or more poor villages, the difficulty level for the village to be out of poverty is higher than the cluster of the non-poor village. As a consequence, it is still easier for a poor village that is surrounded by non-poor villages to be lifted from the poor situation than the poor nearest to the other poor villages. In detail, the result specifies that the cluster of High-High was shaped by the village of Kemiri and Slamparejo. In other words, the focus of the poverty development to the cluster of poor villages, characterized by High-High MPI values is an inevitability. Thus, the poverty alleviation program might focus upon those areas, where social infrastructure development is necessary to be strengthened.

Participation of the community to the existing community groups was quite good. It indicates that the majority of their participation is in the medium 
level. Meanwhile, when the relationship among community members was scrutinized through density index, it showed a bit lower result, where the majority village had a low-density level. It means that at the level of the village, the district does not have strong social capital yet. Hence, it might be concluded that the district poverty is also caused by the weak social ties of the residents since they cannot maximize the utilization of their internal relationship to catch up with both internal and external information and resources for the betterment of their life.

We put together the results of MPI as the dependent variable, access to public facilities, and two indices of social capital as independent variables into spatial regression analysis. The result infers that poverty in the district is affected by quality social ties within community members and neighboring locations. Therefore, paying attention to the poor village which has the nearest physical boundary with another poor village through social infrastructure development as a priority on how to culminate poverty in the district is vital.

This research proposes a more comprehensive approach by putting together three dimensions of poverty: social and physical infrastructures, as well as geographical location, to give a better understanding of poverty in a certain area. Hence, if the approach is applied to other areas, it might give academicians and policymakers the ability to propose a more suitable action plan on dealing with poverty, together with the community members.

\section{ACKNOWLEDGMENT}

The study is funded by the Indonesia Ministry of Research, Technology and Higher Education.

\section{REFERENCES}

Adhi, E. T. (2009). Pelayanan sanitasi buruk akar dari kemiskinan. Jurnal Analisis Sosial. 14, 76-88.

Aminou, F. A. A., \& Zahonogo, P. (2020). Analysis of deprivations suffered by children under five in Benin. Journal of Socioeconomics and Development, 2(2), 125 https://doi.org/10.31328/jsed.v2i2.1219

Anselin, L. (1988). Lagrange multiplier test diagnostics for spatial dependence and spatial heterogeneity. Geographical Analysis, 20(1), 1-17. https://doi.org/10.1111/j.15384632.1988.tb00159.x
Anselin, L. (1995). Local Indicators of Spatial Association-LISA. Geographical Analysis, 27(2), 93-115. https://doi.org/10.1111/j.15384632.1995.tb00338.x

Ari, I. R. D. (2010). Participatory Approach to Community Based Water Supply System. Dissertation. Kyoto: Kyoto University Research Information Repository.

Ari, I. R.D., Hariyani, S., \& Waloejo, B. S. (2019). Neighbourhood relationship among villages in Gedangan District: Multidimensional poverty approach. IOP Conference Series: Earth and Environmental Science (Vol. 328). Institute of Physics Publishing. https://doi.org/10.1088/17551315/328/1/012043

Ari, I. R.D., Hasyim, A. W., Pratama, B. A., Helmy, M., \& Sheilla, M. N. (2017). Infrastructure and social tie: Spatial model approach on understanding poverty in Malang regency, Indonesia. IOP Conference Series: Earth and Environmental Science (Vol. 70). Institute of Physics Publishing. https://doi.org/10.1088/1755-1315/70/1/012017

Ari, Ismu Rini Dwi, Jeong, H., Matsushima, K., \& Kobayashi, K. (2014). Network analysis of community based water management. In Community Based Water Management and Social Capital. IWA Publishing. Volume 13. https://doi.org/10.2166/9781780405469

Ari, I. R. D., Waloejo, B. S., Hariyani, S. (2020). Modelling of poverty eradication in Kedungkandang District, Malang City. International Journal Of Engineering Research \& Technology (IJERT) (09), 05 (May 2020). http://dx.doi.org/10.17577/IJERTV9IS050589

BPS (Central Bureau of Statistics). (2018a). Jumlah Penduduk dan Presentase Penduduk Miskin dan Garis Kemiskinan Menurut Kabupaten/Kota di Jawa Timur Tahun 2018. BPS: Jawa Timur.

BPS (Central Bureau of Statistics). (2018b). Kabupaten Malang Dalam Angka Tahun 2018. ISSN: 02155680 BPS: Kabupaten Malang.

Elia, A., Yulianto, Y., Tiawon, H., Sustiyah, S., \& Indrajaya, K. (2020). Government expenditure and poverty reduction in the proliferation of new administrative areas of Central Kalimantan, Indonesia. Journal of Socioeconomics and Development, 3(2), 145. https://doi.org/10.31328/jsed.v3i2.1410

Gibbs, J. P., \& Coleman, J. S. (1990). Foundations of social theory. Social Forces, 69(2), 625. https://doi.org/10.2307/2579680 
Griffith, D. A., \& Anselin, L. (1989). Spatial econometrics: Methods and models. Economic Geography, 65(2), 160 . https://doi.org/10.2307/143780

Humanitarian Data Exchange. (2020). Indonesia: Global Multidimensional Poverty Index (MPI). Retrieved from https://data.humdata.org/dataset/indonesiampi/resource/c1a8793f-b386-4f47-95054dfee1118c22

KEMENKES RI. (2010). Keputusan Menteri Kesehatan RI No: 1995/MENKES/SK/XII/2010. In Kementerian Kesehatan RI.

Matthews, P. \& Besemer, K. (2014). Poverty and social networks evidence review. Institute for Social Policy, Housing, Environment and Real Estate (ISPHERE), Heriot-Watt University. Retrieved from https://core.ac.uk/download/pdf/42543158.pdf

MPI Research Team. (2015). Modul Pelatihan Perhitungan Multidimensional Poverty Index Indonesia dan Penyusunan Pelaporan MPI Indonesia. Retrieved from http://theprakarsa.org/workshop-pelatihanperhitungan-dan-analisis-multidimensionalpoverty-indexs-mpi-dan-penyusunan-laporan-mpidaerah/

National Planning Board. (2016). National Development Framework.

Ostrom, E., \& Ahn, T. K. (2003). Introduction to Foundations of Social Capital. Edward Elgar
Publishing, 1-24. Retrieved from http://eramx.org/biblio/Ostrom_and_Ahn_2003.pdf

Putnam, R. D. (2001). Reviewed work: Bowling alone: The collapse and revival of American community. Contemporary Sociology, 30(3), 227-230.

Scott, J. (2000). Social Network Analysis: A Handbook. United Kingdom: SAGE Publications. https://books.google.co.id/books?id=MJoIGBfYDG EC

UNDP. (2016). Overview: Human Development Report 2016. United Nations Development Programme, 140. Retrieved from http://hdr.undp.org/en/2016report

Wasserman, S., Faust, K. (1994). Social Network Analysis: Methods and Applications. Hungary: Cambridge University Press. https://books.google.co.id/books?id=CAm2DpIqR UIC

Yamin, S., \& Dartanto, T. (2016). Pengentasan orang miskin di Indonesia: Peran modal sosial yang terlupakan. Jurnal Ekonomi Dan Pembangunan Indonesia, 17(1), 88-102. https://doi.org/10.21002/jepi.v17i1.656

Yuriantari, Nurmalia Purwita, et al. (2017). Analisis autokorelasi spasial titik panas di Kalimantan Timur menggunakan Indeks Moran dan Local Indicator of Spatial Autocorrelation (LISA). Eksponensial. (8), 1, 63-70. Retrieved from http://jurnal.fmipa.unmul.ac.id/index.php/expone nsial/article/view/78 